\title{
Traditional sectors based on natural resources - a blessing or a curse for less developed regions? A case study of Podlaskie Voivodeship
}

\section{Abstract}

The natural environment, as a source of natural resources, has long been perceived as being a factor in determining the development of many states and regions, especially less developed areas. The main research question in this article is what role is played by natural resources and traditional industry sectors based on natural resources (milk production and tourism), in the process of establishing a competitive advantage for Podlaskie Voivodeship, which is one of the less developed regions in Poland. The results of the research reveal weaknesses that are inherent in earlier ways of thinking about these industries and, at the same time, emphasise the importance of making use of natural resources in an integrated way and combining them with new technologies.

Keywords

Natural resources $\cdot$ smart specialisation $\bullet$ less developed regions $\cdot$ milk production $\cdot$ tourism

(c) University of Warsaw - Faculty of Geography and Regional Studies

\author{
Anna Dąbrowska \\ Department of Local Development and Policy, \\ Faculty of Geography and Regional Studies, \\ University of Warsaw, Poland \\ e-mail: a.dabrowska@uw.edu.pl \\ Received: 25 April 2017 \\ Accepted: 2 August 2017
}

\section{Introduction}

This article's main research question is what role is played by natural resources and those traditional industry sectors based on natural resources, in the process of establishing a competitive advantage for less developed regions using the example of Podlaskie Voivodeship in Poland. ${ }^{1}$ This question is of special importance due to the fact that, nowadays, development policies are strongly influenced, on the one hand, by the concept of the knowledge-based economy (Powell \& Snellman 2004) and smart specialisations (Foray 2009, 2015), and on the other by sustainable development (UN 1987) and the green economy (UNEP 2011; UNEP 2012; OECD 2011). While the literature on smart specialization and the associated opportunities for innovative regions has emerged gradually over the last few years, much less attention has been paid to the issue of peripheral regions. The implementation of the smart specialization concept in developed regions is clearly perceived as an opportunity to strengthen their competitive advantages; however, in the case of less developed regions (with a lower level of economic development, a lower innovation potential, poor experience in science-business cooperation, and who are strongly rooted in natural resources) the role of smart specialization is definitely more questionable. Therefore, in particular, an attempt

\footnotetext{
Voivodeship is a unit of territorial self-government in Poland that corresponds to a "province" or "region" in many other countries. Poland's basic territorial divisions include 16 voivodeships at the regional level (corresponding to the EU NUTS II level), 380 districts at the sub-regional level (corresponding to LAU 1 level) and 2,478 communes at the local level (LAU 2). Polish territorial administration at the level of the voivodeship is dualistic, in the sense of the co-existence of organs of the voivodeship selfgovernment and organs of the territorial governmental administration (administration controlled by the central government). In this article the term "voivodeship" will be used interchangeably with the term "region".
}

will be made to answer the following question: Whether smart specializations based on natural resources and traditional industry sectors can provide a sufficiently strong impulse (Pendall, Foster \& Cowell 2010) for diverting peripheral regions from their current development paths (Martin 2011; Sydow, Schreyoegg \& Koch 2009). An attempt to verify the relevance of these factors will be made using the example of Podlaskie Voivodeship, one of the least developed and least populated regions in Poland. Two sectors, which are strongly associated with the natural environment, food processing (in particular milk production) and tourism, will be subjected to a more detailed analysis. The research findings are mostly based on qualitative methods, including in-depth interviews with the regions' main actors and the analysis of strategic documents at the voivodeship level (regional development strategies and RIS - regional innovation strategies), supported by statistical data analysis. The results of the research reveal weaknesses that are inherent in the previous way of thinking about these industries, and, at the same time, emphasise the importance of making use of natural resources in an integrated way and combining them with new technologies. Although the empirical study concentrates on Poland and one Polish region in particular, it may have a wider significance for other less developed and more sparsely populated regions in Poland, as well as similar regions in other countries of the European Union.

This article is structured as follows. First, an overview of the theoretical background is given, which explains the role of natural resources as a development factor, especially in the case of less developed regions. This section is supplemented by a brief analysis of the role of natural resources for Polish voivodeships 
according to their regional strategic documents. Second, the characteristics of the study area (Podlaskie Voivodeship) and the methods used to answer the research question are described. Finally, the empirical section contains a brief description of two important sectors - food processing and tourism - and a discussion concerning their roles in building a competitive advantage for the Podlaskie Voivodeship. Final remarks and conclusions follow at the end of the paper.

\section{Theoretical background}

Natural resources as a development factor

In classical economics, the land, along with its resources was understood to be one of the factors of production; the other two being labour and capital (Smith 2003). The natural environment, as a source of natural resources, is still perceived to be a factor in determining the development of states and regions (especially of less developed areas) (Martin 2011), and also as an autotelic value necessary for the survival of societies, and the human species itself (Domański 2002, pp. 26-27).

However, the results of empirical research from the 1990s clearly indicated that there exists a phenomenon known as the "natural resource curse" (Auty 1993). The term was meant to signify that not only does the abundance of natural resources not constitute the key competitive advantage for all regions, but that it can also result in the inhibition of development (Sachs \& Warner 1997; Gelb \& Associates 1988; Gylfason et al. 1999).

A new way of looking at the role of natural resources and natural factors was created with the dissemination of such concepts as sustainable development, and the green economy but also territorial capital and smart specialization. The green economy narrative has placed the regions that have a high endowment in natural resources in a new position regarding opportunities for investment and growth (Teräs et al. 2015, p. 3). With the concept of territorial capital (OECD 2001; Camagni 2008) came a strong turn towards the specific resources of an area (e.g. natural resources and geographic location, unit size, production capacity, climate, traditions, quality of life and also the benefits of agglomeration) (cf. Wojnar 2013). "This 'territorial capital' generates a higher return for certain kinds of investment than for others since they are better suited to the area and use its unique assets and potential more effectively." (OECD 2001, pp. 15-16). Also, according to the idea of smart specialisation (Foray 2009, 2015) the key to building competitive advantages for regions is the use of the internal economic, scientific, and the R\&D strengths of the regions as well as existing resources.

\section{The role of natural resources for peripheral regions}

Peripheral regions are characterised by a number of key contextual features that strongly influenced their development trajectories and generated a variety of severe problems for local governments (Taylor 2016). Carson, Carson and Lundmark (2014, p. 354) listed the structural weaknesses of remote areas: the sparse and dispersed populations, a lack of critical mass in actors and infrastructure, and the "thin" and fragile network connections. Hall and Boyd (2005) also indicated insufficient political and economic control over major decisions, which affected the wellbeing of these remote areas, and a greater interventionist role by the national government (due to the economic difficulties of the region). Another complex issue for sparsely populated areas is given by the concept of the "Eight Ds" (Carson \& Carson 2014; Carson, Carson \& Lundmark 2014), which identifies a number of key characteristics in which settlements are described as diverse, distant, dependent, disconnected, discontinuous, dynamic, detailed and delicate.

The development of peripheral regions is often based on traditional economic sectors driven by endogenous resources, in particular natural and environmental resources (e.g. food processing, wood processing, and the furniture industry, as well as tourism) (Kudetko 2013). Abandoning the narrow understanding of innovation and opting for the inclusive definition of smart specialisation meant giving "every sector a chance to be present in the strategy through a good project" (Foray \& Goenega 2013, pp. 7-8), which could also be applied to sectors that are not traditionally considered to be innovative. These economic sectors are often of lower efficiency and productivity and it is therefore doubtful they would lead to a decrease in the distance that separates the less developed regions from the growth leaders (Nazarko 2014). As indicated by the results of recent research, the implementation of RIS3 in areas that struggle with multiple challenges (e.g. resulting from low population density or the agricultural nature of the region) "tends to give back a more prominent place to natural resources in regional development strategies (...) and enabled regions to find 'smarter' avenues for ensuring the continued development of the primary sector, as well as inducing crossovers with other sectors" (Dubois et. al 2016, p. 10).

The concept of smart specialisations explicitly emphasises the need for rejuvenating traditional sectors through higher valueadded activities and new market niches. Nanotechnology is, for example, used in the food sector in Portugal to improve quality control in the production of cheese, wine and olive oil, and in the pulp and paper industry in Finland to improve operational efficiency. Biological applications of nanotechnology can also be found in Galicia's marine resources sector, while its ICT applications are common in the tourism sector where they are used to improve the quality of services and reduce queues for attractions (Arancegui et al. 2011, p. 4; David, Foray \& Hall 2009; Foray \& Goenaga 2013, p. 4).

Smart specializations can also be seen as an opportunity for less developed Polish regions. The analysis of the regional strategies of Polish voivodeships has demonstrated that natural resources, and the potential associated with them (e.g. in the form of economic sectors created due to the use of said resources, i.e. scientific and research potential arising from the specificity of the resources, etc.), are often understood to be strategic resources in the case of less developed voivodeships (eastern Poland). The relevance of environmental advantages in SWOT analyses is significantly higher in the case of the less developed voivodeships of eastern Poland than in the case of other voivodeships (Figure 1). ${ }^{2}$

Analysis of the identified smart specialisations of Polish voivodeships also points to the significant role of sectors that are directly related to the environment (e.g. bio-economy, health tourism) or natural resource based industries (e.g. renewable energy systems, healthy food, wooden furniture industry) (Dziemianowicz, Szlachta \& Peszat 2014, pp. 74-75). In this case, however, there is definitely a greater variation between voivodeships. For example, all three smart specialisations of Warmińsko-Mazurskie Voivodeship (water economy, high quality food, and wood and furniture) are based on the environmental potential of the region, whereas in the case of Podkarpackie Voivodeship and Pomeranian Voivodeship - which represent the other extreme - the ties with the natural environment are much less prominent (Figure 2). It is worth noting that there are three voivodeships in eastern Poland that are characterized by lower levels of economic development (Warmińsko-Mazurskie,

2Own elaboration, based on SWOT analyses used in regional development strategies of all 16 Polish regions (January 2017). According to the methodology used only strengths from SWOT analyses were taken into account, because, in simplified terms, they described strategic competitive advantage of a given region. Based on these assumptions it can be stated that the share of "environmental" indicators in the strengths listed range from $17 \%$ in Kujawsko-Pomorskie and Mazowieckie Voivodeship to $40 \%$ in Świętokrzyskie Voivodeship. 


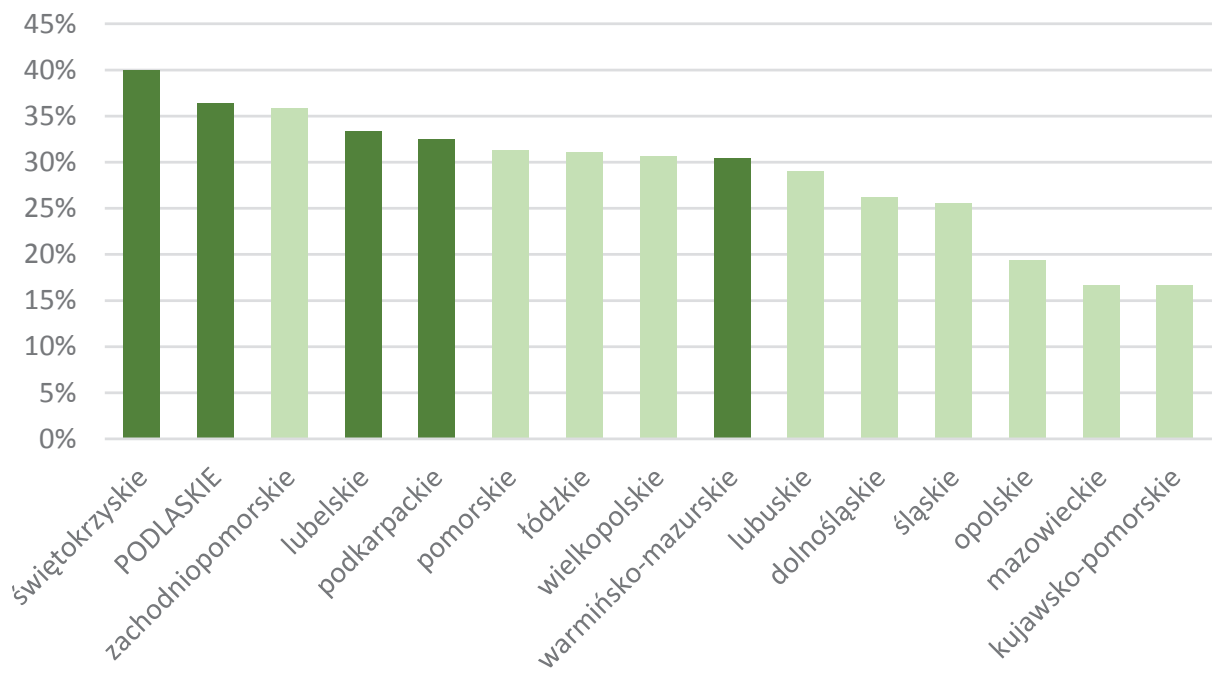

Figure 1. Significance of natural resources in the context of the development strategies of Polish voivodeships (the share of strengths related to natural resources as part of total number of strengths identified in the SWOT analysis)

Source: the author's own research based on the development strategies of voivodeships (as at: January 2017).

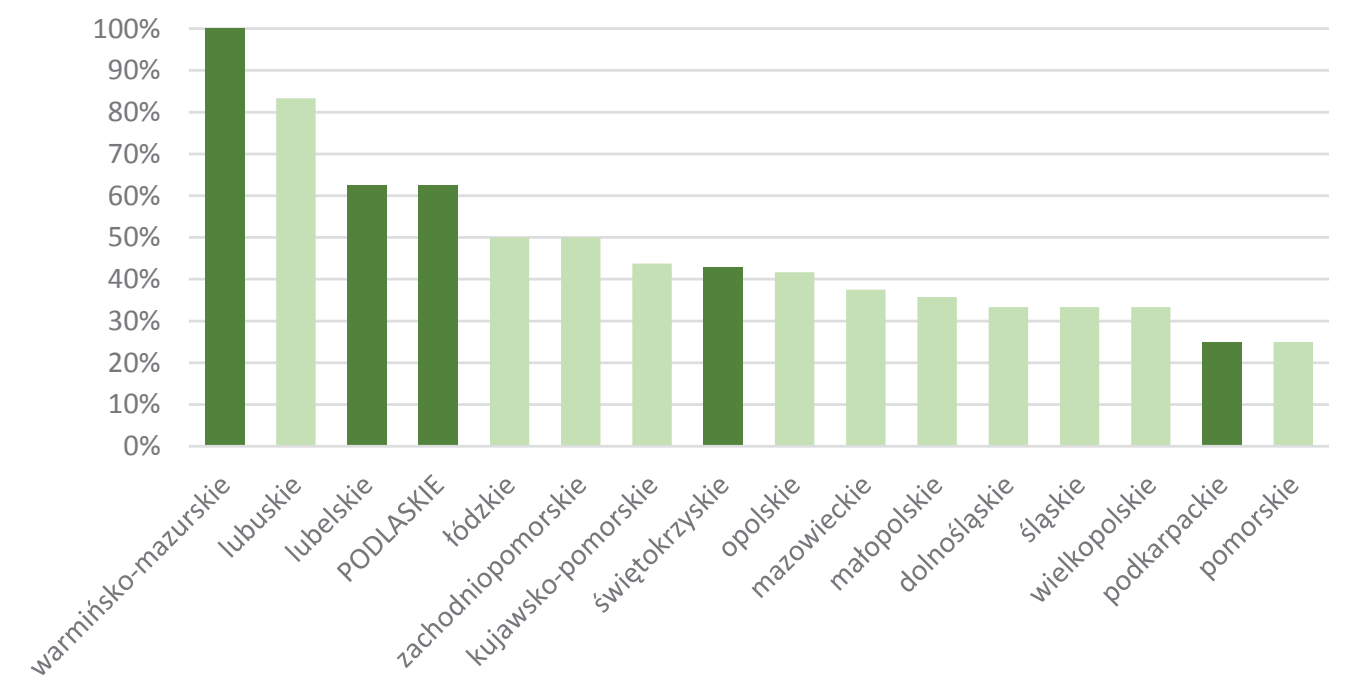

Figure 2. The importance of natural resources in the context of smart specializations of Polish voivodeships (the share of smart specializations related to natural resources as part of total number of smart specialisations of the voivodeship)

Source: the author's own research based on documents specifying regional smart specializations of particular voivodeships (as at: March 2017).

Lubelskie, and Podlaskie) among the four regions that assign most importance to their natural resources in the context of their smart specialisations.

The case of Podlaskie Voivodeship

Podlaskie Voivodeship is a region characterised by particular developmental challenges related to specific territorial and socioeconomic conditions.

First of all, it is a peripheral region, both in purely geographical terms and in economic terms (Olechnicka 2004, p. 140). Located in north-eastern Poland, it borders Lithuania and Belarus (which is also a European Union external border). The peripheral character of the voivodeship is visible, among other things, in its low level of urbanization, poor accessibility ${ }^{3}$ and low level of economic development. GDP per capita is at a level of less than $73 \%$ of the national average, which means that the voivodeship is one of the four poorest regions in Poland ${ }^{4}$ In the European rankings

${ }^{3}$ Its disadvantageous position in terms of accessibility of the region placing it in an accessibility range similar to that of the Nordic Northern Periphery (Zaucha et al. 2014).

${ }^{4}$ It is a region that receives additional support from European Funds targeting the poorest areas in the EU. In 2007-2013, it was funded by the Operational Programme Development of Eastern Poland 2007-2013, while in the current financial period, support is provided by the Operational Programme Eastern Poland 2014-2020. 
presenting GDP values per capita calculated at purchasing power parity (PPS), the voivodeship was classified at a very low ranking out of all 268 regions of the EU (eighteenth position from the bottom); but this still indicated an improvement in comparison with data from 2000.

Secondly, it is a region with a low population density. Even though the voivodeship's population density exceeds, by several times, the rate of sparsely populated regions (12 persons $/ \mathrm{km}^{2}$ in NUTS3 regions), it is nevertheless characterised by features that are typical for this type of region (Gløersen et al. 2006):

- $\quad$ low population with scattered small settlement structures Podlaskie, with its $1,189,000$ inhabitants is one of the least populated regions in Poland, and it is, at the same time, the region with the lowest population density in the country (59 persons $/ \mathrm{km}^{2}$, whereas the average for Poland is 123 persons $/ \mathrm{km}^{2}$ ) (Powierzchnia i ludność w przekroju terytorialnym w 2016 r., 2016, pp. 12-13). Demographic projections indicate a further decline in population (by 212,000 people by 2050), worsening the negative natural growth rate to a level of -6.9 , and the continuous ageing of society.

- $\quad$ harsh climatic conditions - the voivodeship has the shortest vegetation growing period in Poland, large temperature drops, a long period of snow retention, the highest average annual wind speed, as well as periodic water shortages.

- $\quad$ long distances to main urban centres - the voivodeship has low external transport accessibility but also relatively unfavourable indicators for internal transport accessibility (in terms of transportation links leading to the capital of the voivodeship, Białystok).

- $\quad$ abundance of natural resources - Podlaskie is a green region, which manifests itself in two ways. First of all, the voivodeship's territory includes some of the most valuable natural areas in the country (and the whole of Europe) in particular, Białowieża Primeval Forest, Augustów Primeval Forest, and Knyszyna Forest, as well as the Biebrza and Narew marshes. Secondly, its large share of permanent grassland areas (in particular meadows and pastures) is also a natural resource, as it is the basis for cattle raising and milk production, which determines the strength of agriculture in the voivodeship. In 2015, 24\% of the population was employed in the agricultural sector, and agriculture accounted for $8.7 \%$ of GDP of the voivodeship (with $3.1 \%$ being the average for Poland).

\section{Methodology}

Individual, in-depth interviews with the main actors of the region ${ }^{5}$ was the primary method used to identify the factors that have been determining the development of Podlaskie Voivodship over the last fifteen years. They were also used to attempt to define the role of the factors related to natural resources in this development process. Statistical data analysis was employed in a supporting role (data from the Central Statistical Office and Eurostat). Strategic documents at the voivodeship level (regional development strategies and regional innovation strategies) were also analysed, including historical documents; while the strategic documents of other voivodeships were used as a form of research background for the study.

${ }^{5}$ In total thirteen in-depth interviews were conducted for this study, with such people as representatives of the Marshal's Office (representative of the ROP Implementation Department and Regional Territorial Observatory, as well as a former representative of the Department of Regional Development), an advisor to the voivodeship's marshal, as well as representatives of local self-governments (of Suwałki and Łomża), higher education institutions (rector of the University of Białystok and a representative of the Faculty of Economics and Management of University of Białystok), institutions of the voivodeship's business environment (Podlaska Regional Development Foundation in Białystok, Białystok Science and Technology Park), self-regulatory organizations (Chamber of Industry and Commerce in Białystok), clusters (Metal Processing Cluster) and entrepreneurs.
The role of natural resources in the development of Podlaskie Voivodeship - research results

The development of Podlaskie Voivodeship has long been based on its natural resources. Their significance in building the competitive advantage of the region is emphasized clearly in the strategic documents, both those that are currently binding and those that came before them (voivodeship development strategies from 2000, 2006 and 2013, as well as the Plan rozwoju przedsiębiorczości w oparciu o inteligentne specjalizacje województwa podlaskiego na lata 2015-2020 + (RIS3) (2015). Two sectors, food processing (in particular milk production) and tourism, will be analysed in more in-depth.

\section{Food processing}

Agriculture is the dominant sector of Podlaskie Voivodeship's economy despite unfavourable environmental, climatic and soil conditions (shortest vegetation growth period in Poland, sharp falls in temperature, the predominance of soil types of the fourth and fifth quality class, and regular water deficits), resulting in Podlaskie Voivodeship having the lowest valorisation index value for agricultural production area among all the Polish voivodeships (Jończyk, Kuś \& Madej 2010, p. 137). Cattle raising and milk production play the key role due to the fact that the voivodeship has a large share of permanent grassland areas (in particular meadows and pastures) and the fact that other conditions for development of agriculture are unfavourable. Podlaskie Voivodeship has the second highest number of cows in the country (almost $20 \%$ ), only slightly lower than the much bigger Mazowieckie Voivodeship (Rocznik statystyczny rolnictwa 2015). This translates into the following results:

- $\quad$ at the voivodeship level: the food industry (based on milk processing) generates almost $50 \%$ of sold produce and employs $30 \%$ of the overall number of people employed in industry (Domański 2011, p.27).

- $\quad$ at the country level: Podlaskie Voivodeship accounts for $6 \%$ of all dairy companies (as a proportion of the whole country); $18 \%$ of people employed in the dairy industry; $20 \%$ of national milk purchases; about $25 \%$ of the overall sales value; $20 \%$ of gross value added; about $25 \%$ of total capital expenditure for the purchase of fixed assets incurred by the industry in 2010; $30 \%$ of the total domestic production of processed liquid milk, as well as butter, cheese and curd; and a $11 \%$ share in domestic exports of this product (Strategia Rozwoju Województwa Podlaskiego do roku 2020, 2013, p.19). ${ }^{6}$

Yet, the very thing that speaks of the strength of the dairy industry, paradoxically, also demonstrates the specific weakness of the region's economy. The concentration of significant labour resources in the low-efficiency agricultural sector, combined with the productivity of the remaining sectors of the economy being lower than the national average, results in a generally low labour productivity for the region when compared to other voivodeships.

If we look at the performance statistics in agriculture, we are the leaders of the country (...) The largest dairies are in our region. It's a factor that, on the one hand, allowed us to move forward, but, at the same time, functions as a brake on our development. A very large part of the population continues to earn their living in the agricultural sector, where productivity is lower than in other sectors.

(Daniel Górski, former Director of the Department of Regional Development at the Marshal's Office of Podlaskie Voivodeship,

Development Director of UNIBEP SA) (Author's translation)

${ }^{6}$ The highest concentration of companies representing the food industry can be found in the poviats of Grajewo, Mońki, Łomża, Wysokie Mazowieckie, Bielsko and Siematycze. 
The strength of Podlaskie Voivodeship in the dairy industry is based mainly on the strength of the following two big companies: Mlekovita from Wysokie Mazowieckie and Mlekpol from Grajewo. In 2014, their turnovers amounted to PLN 3.9 and 3.6 billion respectively, that is, the two best results in the dairy industry in Poland. ${ }^{7}$ Mlekpol currently has twelve production plants (including seven in Podlaskie Voivodeship) and Mlekovita fifteen (only one of which is in Podlaskie Voivodeship - the parent facility is located in Wysokie Mazowieckie). About $30 \%$ of both companies' output is exported to various countries around the world. The export of dairy products accounts for almost one-third of the total exports of Podlaskie Voivodeship.

The development policies of Mlekovita and Mlekpol deserve a closer look in this context. Mlekovita opened a production plant in Kaliningrad in 2009. In 2014 it opened a research and development centre in Wysokie Mazowieckie. The R\&D centre is designed to support the company in the development of innovative and safe manufacturing technologies. Mlekovita also began to open cash-and-carry wholesalers, as part of the development of its value chain. The company, which has more than 800 products in its offer, launched 116 new products in 14 categories in 2015 alone. Mlekpol also makes available large amounts of money for innovative activities; investment involves both the uptake of technological processes and the development of new products targeted at different consumer groups. The market policy of the company is particularly positive. Promoting the "Łaciate" brand was a milestone in the company's development. It is currently the best-known brand in dairy products and one of the most expensive brands in Poland (Edmund Borawski - Twórca Krainy Mlekiem Płynącej 2016).

The specifics of these companies is that they operate in the form of cooperatives owned by workers and primarily milk suppliers, which is perceived by the owners of Mlekpol and Mlekovita as a key factor in the success of the dairy industry in Podlaskie.

It is also worth mentioning that, according to the food processing industry (especially the dairy industry), smart specializations in Podlaskie Voivodeship are considered from the perspective of value chains. For example, a printing company that produces food packaging is considered smart in the value chain of the agro-food industry. Another example may be an IT company that produces software for dairies (cf. Miara 2016). It creates new opportunities for cooperation between different firms and for the development of other sectors linked by value chains with the agri-food industry (e.g. logistics, distribution, ICT for the agri-food sector, production of high quality and traditional food).

\section{Tourism}

The voivodeship's territory includes some of the most valuable natural areas in the country, and in Europe; in particular Białowieża Primeval Forest, Augustów Primeval Forest, and Knyszyna Forest, as well as the Biebrza and Narew marshes (Strategia Rozwoju Województwa Podlaskiego do roku 2020, 2013, p.17). The Białowieża National Park protects the best preserved fragment of Białowieża Primeval Forest, the last natural primeval forest in Europe, and is therefore the only natural heritage site in Poland to be included on UNESCO's World Heritage List. National parks within the voivodeship account for nearly $30 \%$ of the total area of national parks in Poland. Because of this, for many years, the prevailing belief was that the strength of the region could be rested upon the basis of its attractiveness for tourism; this was reflected in subsequent strategic documents (Strategia Rozwoju Województwa Podlaskiego do 2010 r., 2000, Strategia Rozwoju Województwa Podlaskiego do 2020 roku, 2006).

${ }^{7}$ For comparison, Polish branches of international corporations Danone and Zott both achieved three times lower turnover (Forum mleczarskie 2016).
However, nowadays, the development of tourism is determined not by natural resources alone, but mainly by the broadly-understood tourist infrastructure (Kozak 2010, p. 54), which in Podlaskie Voivodeship is relatively underdeveloped. When Polish voivodeships are ranked in accordance with their tourism potential (which includes natural, cultural, historical and contemporary factors, as well as factors related to infrastructure and economy), Podlaskie voivodeship is classified thirteenth, ahead of Lubelskie, Opolskie and Świętokrzyskie voivodeships (Szymańska 2015, p. 53). ${ }^{8}$ The most important factor determining the low position of the region is its low level of tourism development (the small number of hotels and other elements of tourist and catering infrastructure). The Augustów Lake District, Upper Narew Valley and Białowieża Primeval Forest are the most developed areas in terms of tourism (Derek 2012), but overall, in comparison with other voivodeships (including other voivodeships of eastern Poland), Podlaskie Voivodeship is characterised by a lower share of communes that have the highest level of development of tourism function, as well as a big share of communes that have the lowest level of tourism function development. In Podlaskie Voivodeship, 23\% of communes belong to the first quartile of communes in Poland that have the most developed tourist function (for example, in Warmińsko-Mazurskie Voivodeship, the region of eastern Poland with most well-developed tourist infrastructure, the result was $44 \%$ ), and $37 \%$ of communes belong to the last quartile (in Warmińsko-Mazurskie Voivodeship, the percentage was 12\%).

The climatic conditions of the region are also a factor that strongly hinders the development of large-scale tourism, as the tourist season is only two months long and therefore cannot be the basis for building a large-scale tourism industry.

We have a nice region, nice forests, lakes, landscapes; it is lovely, but if we talk about the economy, then we have to talk in economic terms. The tourist season lasts only two months, so it is impossible to turn tourism into business here.

(Marek Dźwigaj, Vice-Chairman of the Board of the Podlaska Regional Development Foundation in Białystok)

Nowadays there seems to be more and more doubts about the tourism potential of Podlaskie Voivodeship. What is more, it is slowly becoming clear that because the development of the voivodeship was, for many years, conceptualised on the basis of its natural values, the image of the voivodeship has become focused solely on its green and natural character, unspoilt by any industry. Research concerning the image of Podlaskie Voivodeship, which was carried out for the purpose of building the region's brand, clearly indicated that while people who live in Podlaskie Voivodeship associate it with agriculture and the dairy industry, people from other voivodeships perceive it primarily as a region that has hardly been damaged by civilization - completely natural and attractive for tourism (Województwo Podlaskie - wizerunek i zasady komunikacji marki, p. 37). People from other voivodeships focus almost exclusively on such symbols as wilderness, nature, bison, and storks, and even the largest dairy companies - Mlekpol and Mlekovita - are not commonly associated with Podlaskie Voivodeship. However, occasionally, this image of wild nature and primeval landscape, together with the symbolic figure of the bison, becomes synonymous with the lag of civilization and primitive living conditions.

We still have serious problems when we take part in trade fairs (...) For example, in Poznań, we were asked if there is

\footnotetext{
${ }^{8}$ When compared with other Polish voivodeships, Podlaskie Voivodeship does best in terms of natural factors (7th place), significantly worse when it comes to economic factors (11th place), historical, cultural and contemporary factors (14th place) and infrastructure-related factors (15th place) (Szymańska 2015).
} 
even a technology university in Podlaskie Voivodeship? And if there is one, does it do any worthwhile stuff (...) Years of building an image on the basis of storks and bison resulted in us being perceived this way. We have done it to ourselves.

(Author's emphasis) (Sebastian Rynkiewicz, a coordinator at the Metal Processing Cluster)

\section{Conclusions}

Perhaps the wealth of natural resources (or any other arbitrary circumstances) can start a local development process, however, in the long term, such factors cannot keep the process going (Sätre Åhlander, p. 126). It seems that whether natural resources become a blessing or a curse for regional development depends on the way these resources are used by the region. Numerous examples from various countries indicate that it is possible to make use of natural resources in an integrated way, combining historical legacy with new technologies to meet emerging societal demands (Rosa Pires, Pertoldi, Edwards \& Hegyi 2014, p. 7), and thus create competitive advantage in the region. The critical requirements for the relevant use of natural resources for a region's development are human and social capital, because these are the means by which other forms of capital are produced, and the specific aspects of the natural environment are turned into economic resources and the well-being of the region (Hall \& Boyd 2005, p. 4; Zaucha et al 2014).

The implementation of the concept of smart specialisations in Podlaskie Voivodeship may result in a gradual change in ways of thinking about the region's traditional competitive advantages. The importance of cooperation between the welldeveloped science sector (life sciences) and the agri-food industry continues to grow steadily, particularly, in the case of the dairy industry, which constitutes the core of the region's smart specialisation. What is more, the production of high quality food and traditional food, as well as the development of information and communication technologies for the agri-food sector are treated as matters of particular significance for the voivodeship (Plan rozwoju przedsiębiorczości... 2015).
On the one hand, the idea of tourism as the dominant driving power of the region has been replaced by a narrower focus on health tourism; this is strongly linked to the region's potential in terms of the development of medical science and industries related to rehabilitation, physical therapy, the Silver Economy and care for the elderly. It seems that the changes in the ways of thinking about the voivodeship's development may create an opportunity for reducing the identified vulnerabilities that are related to development based on natural resources. On the other hand, the concept of smart specialization that has been implemented in Podlaskie Voivodeship, and also in other regions of eastern Poland, focuses on a "diffused search for innovation" (Dziemianowicz \& Peszat 2016) instead of an "overly narrow specialisation". Smartspecializations within Podlaskie Voivodeship are treated quite broadly; this results from the belief that less developed regions cannot afford to waste their opportunities, which may even consist of individual projects implemented by innovative firms. Therefore, it seems more likely that in the near future we can expect success stories from individual companies or groups of companies and clusters and increasing innovation and competitiveness, whereas changing the development path of the whole region and moving to higher levels of innovation requires a little bit more time (Camagni \& Capello 2013).

\section{Acknowledgment}

This paper is based on the result of the "Changing innovation processes models: A chance to break out of path dependency for less developed regions" research project funded by Narodowe Centrum Nauki (National Science Centre, Poland) grant number DEC-2014/13/B/HS5/03612. The grant was awarded to the University of Warsaw, Faculty of Geography and Regional Studies.

\section{References}

Arancegeui, MJ, Querejata, MJA \& Montero, EM 2011, Smart Specialisation Strategies: The Case of the Basque Country, Orkestra Working Paper Series in Territorial Competitiveness.

Auty, RM 1993, Sustaining development in mineral economies: the resource curse thesis, Routledge, London.

Camagni, R 2008, 'Regional Competitiveness: Towards a Concept of Territorial Capital', in Modelling regional scenarios for the enlarged Europe, eds R Camagni, R Capello, B Chizzolini \& U Fratesi, Springer, Berlin, pp. 33-48.

Carson, DB \& Carson, DA 2014, 'Local economies of mobility in sparsely populated areas: Cases from Australia's spine', Journal of Rural Studies, vol. 36, pp. 340-349.

Carson, DB, Carson, DA \& Lundmark, L 2014, 'Tourism and Mobilities in Sparsely Populated Areas: Towards a Framework and Research Agenda', Scandinavian Journal of Hospitality and Tourism, vol. 14 (4). pp. 353-366.

David, P, Foray, D \& Hall, B 2009, Measuring Smart Specialization: The concept and the need for indicators. Available from: <http://cemi.epfl.ch/files/content/sites/cemi/ files/users/178044/public/Measuring smart specialisation. doc> [20.03.2017].

Derek, M 2012, Wskaźnik funkcji turystycznych gmin w Polsce, Geoprofit, unpublished.

Domański, B (eds.), Dej ,M, Działek, J, Gwosdz, K \& SobalaGwosdz, A 2011, Znaczenie przemysłu dla „inteligentnego i trwałego" rozwoju regionu Polski Wschodniej oraz podejmowanych działań dotyczących jego restrukturyzacji $i$ modernizacji, ekspertyza na zlecenie Ministerstwa Rozwoju Regionalnego na potrzeby aktualizacji Strategii rozwoju społeczno-gospodarczego Polski Wschodniej do roku 2020.

Domański, R 2002, Gospodarka przestrzenna, Wydawnictwo Naukowe PWN, Warszawa.

Dubois, A, Teräs, J, Sörvik, J \& Pertoldi, M 2016, Smart Specialisation in Sparsely Populated areas - Challenges, Opportunities and New Openings, conference paper presented at the SMARTER conference Seville.

Dziemianowicz, W \& Peszat, K 2016, 'Inteligentne specjalizacje w polskich regionach peryferyjnych w świetle dotychczasowej regionalnej polityki wspierania innowacyjności', Studia KPZK PAN, tom CLXX, Warszawa, pp. 278-291.

Dziemianowicz, W, Szlachta, J \& Peszat, K 2014, Potencjały rozwoju i specjalizacje polskich województw, Ministerstwo Infrastruktury i Rozwoju, Warszawa.

'Edmund Borawski - Twórca Krainy Mlekiem Płynącej', Podlaski Manager, vol. 177, July-August 2016.

Foray, D \& Goenaga, X. 2013, 'The Goals of Smart Specialization', S3 Policy Brief Series, no. 01/2013, JRC-IPTS, Seville.

Foray, D 2009, Understanding "Smart Specialisation", in the questions of R\&D Specialisation: Perspectives and Policy Implications, Institute for Perspective Technological Studies - Joint Research Centre, Seville. 
Foray, D 2015, Smart Specialisation: Opportunities and Challenges for Regional Innovation Policy (Regions and Cities), Routledge.

Forum mleczarskie 2016. Available from: <http://www. forummleczarskie.pl/FIRMY/TOP/>. [20.11.2016].

Gelb, AH \& Associates 1988, Oil Windfalls: Blessing or Curse?, Oxford University Press, New York.

Gløersen, E, Dubuois, A, Copus, A \& Schürmann, C 2006, Northern peripheral, sparsely populated regions in the European Union and in Norway, Nordregio Report, 2, Stockholm.

Gylfason, T, Herbertsson, TT \& Zoega, G 1999, 'A mixed blessing: Natural resources and economic growth', Macroeconomic Dynamics, vol. 3, pp. 204-225.

Hall, M, \& Boyd, S (eds.) 2005, Nature-Based Tourism in Peripheral Areas: Development or Disaster, Channel View Publications, Clevedon, UK.

Jończyk, K, Kuś, T \& Madej, A2010, 'Stan rolnictwa ekologicznego i uwarunkowania jego rozwoju na obszarze województwa podlaskiego', Journal of Research and Application in Agricultural Engineering, vol. 55(3), pp. 137-141.

Kozak, M 2010, 'Turystyka: niewykorzystana szansa rozwojowa regionów?', Studia Regionalne i Lokalne, vol. 4(42), pp. 43-59.

Kudełko, J 2013, 'Uwarunkowania i kierunki rozwoju województwa Polski Wschodniej jako regionów słabo rozwiniętych', Studia KPZK PAN, tom CLI, Warszawa.

Martin, R 2011, 'Regional economies as path-dependent systems: some issues and implications', in Handbook of Regional Innovation and Growth, eds P Cooke, B Asheim, R Boschma, R Martin, D Schwartz \& F Todtling, Edward Elgar, Cheltenham, pp. 198-210.

Miara, A 2016, 'Regionalne specjalizacje województwa podlaskiego - przykład budowania specjalizacji polskich regionów' Studia KPZK PAN, tom CLXX, Warszawa, pp. 292-303.

Nazarko, Ł 2014, 'Inteligentne specjalizacje polskich regionów przyczynek do ewaluacji', Przedsiębiorczość i Zarządzanie, vol. XV(8), part 1, pp. 247-262.

OECD, 2001, Territorial Outlook. Territorial Economy, OECD, Paris.

OECD, 2011, Towards Green Growth, OECD Publishing.

Olechnicka, A 2004, Regiony peryferyjne w gospodarce informacyjnej, Wydawnictwo Naukowe "Scholar", Warszawa.

Plan rozwoju przedsiębiorczości w oparciu o inteligentne specjalizacje województwa podlaskiego na lata 20152020+ (RIS3), 2015, Departament Rozwoju Regionalnego Urzędu Marszałkowskiego Województwa Podlaskiego przy współpracy ekspertów firmy Geoprofit: Wojciecha Dziemianowicza i Roberta Girejko.

Pendall, R, Foster, KA \& Cowell, M 2010, 'Resilience and regions: building understanding of the metaphor', Cambridge Journal of Regions Economy and Society, vol. 3(1), pp. 71-84.

Power, W \& Snellman, K 2004, 'The knowledge economy', Annu. Rev. Sociol, pp. 199-220.

Powierzchnia i ludność w przekroju terytorialnym w 2016 r., 2016, Główny Urząd Statystyczny, Warszawa.

Rocznik Statystyczny Rolnictwa 2015, 2015, Główny Urząd Statystyczny.

Rosa Pires, A, Pertoldi, M, Edwards, J \& Hegyi, FB 2014, 'Smart Specialisation and Innovation in Rural Areas', S3 Policy Brief Series, no. 09/2014, JRC-IPTS, Luxembourg.
Sachs, J, D, Warner, A, M 1997, Natural resource abundance and economic growth, Center for International Development and Harvard Institute for International Development, Cambridge.

Sätre Åhlander, AM 2003, 'The social economy - a level for local economic development?' in Local Responses to Global Changes. Economic and Social Development in Northern Europe's Countryside, eds L O Persson, A-M Sätre Åhlander \& $H$ Westlund, National Institute for Working Life \& author, Stockholm, pp. 109-128.

Smith, A 2003, The Wealth of Nations: An Inquiry into the nature and Causes of the Wealth of Nations, Bantam Classics, New York, (first published in 1776).

Strategia Rozwoju Województwa Podlaskiego do 2010 r., 2000, Urząd Marszałkowski Województwa Podlaskiego, Białystok.

Strategia Rozwoju Województwa Podlaskiego do 2020 roku, 2006, Urząd Marszałkowski Województwa Podlaskiego, Białystok.

Strategia Rozwoju Województwa Podlaskiego do roku 2020, 2013, Urząd Marszałkowski Województwa Podlaskiego, Białystok.

Sydow, J, Schreyoegg, G \& Koch, J 2009, 'Organizational path dependence: Opening the black box', Academy of Management Review, vol. 34(4), 689-709.

Szymańska, E (ed) 2015, Wpływ projektów z zakresu turystki $i$ kultury na rozwój społeczno-gospodarczy regionu. Pozycja turystyki województwa podlaskiego na tle kraju i Europy, Urząd Marszałkowski Województwa Podlaskiego, Białystok.

Taylor, A 2016, 'Introduction: settlements at the edge', in Settlements at the Edge: Remote Human Settlements in Developed Nations, eds A Taylor, D Carson, P Ensign, L Huskey, R Rasmussen, Edward Elgar, Cheltenham.

Teräs, J, Dubois, A, Sörvik, J \& Pertoldi, M 2015, 'Implementing Smart Specialisation in Sparsely Populated Areas', S3 Working Paper Series, no. 10/2015.

United Nations, 1987, Report of the World Commision on Environment and Development: "Our Common Future”.

United Nations Environment Programme (UNEP), 2011, Towards a Green Economy: Pathways to Sustainable Development and Poverty Eradication.

United Nations Environment Programme (UNEP), 2012, Green Economy Policy Briefs - key issues for the transformation towards the Green Economy.

Województwo podlaskie - wizerunek i zasady komunikacji marki. Available from: <http://podlaskamarka.pl/wp-content/ uploads/2016/01/Zasady_komunikacji_marki_Wojew_. dztwo Podlaskie.pdf> [20.02.2017].

Wojnar, K 2013, 'Ocena oddziaływania na terytorium jako instrument polityki przestrzennej', in Terytorialny wymiar rozwoju. Polska z perspektywy badań ESPON, eds A Olechnicka, K Wojnar, Wydawnictwo Naukowe Scholar, Warszawa, pp. 12-30.

Zaucha, J, Komornicki, T, Böhme, K, Świątek, D \& Żuber, P 2014 'Territorial Keys for Bringing Closer the Territorial Agenda of the EU and Europe 2020', European Planning Studies, vol. 22:2, pp. 246-267, DOI: 10.1080/09654313.2012.722976. 